\title{
РОССИЯ И ЗАПАД: КОНСТИТУЦИОННОЕ ПРАВО ГРАЖДАН НА СОЦИАЛЬНОЕ ОБЕСПЕЧЕНИЕ - ИНДИКАТОР СОЦИАЛЬНОСТИ ГОСУДАРСТВА
}

\begin{abstract}
Аннотация: В статье исследовано понятие социального государства, его взаимосвязь с конституционнылм правом граждан на социальное обеспечение. Проанализированы конституции зарубежных стран на предмет закрепления приниипов сочиальной политики государства, элементов права на социальное обеспечение. Предметом исследования настоящей статьи является вопрос реализации конституциионного права граждан на социильное обеспечение в Российской Федерации и западных странах, выступающего индикатором социальности государства. Показана проблематика внедрения и развития новых элементов при реализации права на социиальное обеспечение, тенденции его развития в постиндустриальном обществе. Указанные вопросы исследуются с помощью логического и системного методов, анализа и синтеза, формально-юридического, сравнительно-правового и историко-сравнительного методов познания. В статье выдвигается и обосновывается тезис о том, что конституцуионое право граждан на социальное обеспечение является основным индикатором социальности государства. Построение социального государства через реализацию конституционного права на социильное обеспечение - стратегическая задача как государственного аппарата, так и обязанность и забота каждого отдельного гражданина и общества в целом, решаемая только на основе взаимной ответственности.
\end{abstract}

Abstract: The article examines the concept of the social state and its relationship with the constitutional right of citizens to social security. The author considers the constitution of various foreign countries in order to find whether the principles of social policy of the state and the right to social security are consolidated. The subject of present paper is the constitutional right of citizens to social security in the Russian Federation and Western countries being indicators of the social state. The authors reveals the problems of introduction and development of new elements in the implementation of the right to social security as well as its development in the post-industrial society. These issues are investigated using logical and systematic methods of analysis and synthesis, formal, legal, comparative legal, historical and comparative methods of cognition. This article extends and substantiates a thesis according to which the constitutional right to social security is the main indicator of the welfare state. Building a social state through the implementation of the constitutional right to social security is a strategic task of the state apparatus as well as an obligation and concern of each individual citizen and society as a whole; in order to solve it, mutual responsibility is required.

Ключевые слова: Конституичя, социальное государство, государство благосостояния, социильное обеспечение, бедность, государственная сочиальная помощь, сочиальные услуги, качество, бизнес, дорожная карта

Keywords: Constitution, the social state, the welfare state, social security, poverty, state social assistance, social services, quality, business, roadmap.

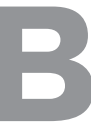

соответствии со ст.7 Конституции Российской Федерации «Российская Федерация - социальное государство, политика которого направлена на создание условий, обеспечивающих достойную жизнь и свободное развитие человека» ${ }^{1}$

Идея социального государства в научной мысли существует несколько столетий, по мнению одних

\footnotetext{
${ }^{1}$ См.: Конституция Российской Федерации (принята всенародным голосованием 12.12.1993) (с учетом поправок, внесенных Законами РФ о поправках к Конституции РФ от 30.12.2008 № 6-ФК3, от 30.12.2008 № 7-ФКЗ). Собрание законодательства РФ., 26.01.2009. № 4. ст. 445.
}

исследователей, она впервые прозвучала в период английской революции, когда в Акте 1649 года, получила конституционное воплощение в тезисе об объявлении Англии общим достоянием. В этой формуле общего состояния богатства подчеркивалось, что государство должно выполнять функции социальные. Следующий этап наступил в ходе американской революции, когда Декларация о независимости 1788 г. провозгласила как самоочевидную истину, что все рождены свободными и что каждый наделен определенными, неотчуждаемыми правами, в том числе правом на жизнь, правом на свободу и правом на стремление к счастью. Если говорить об исламском мире, впервые идея социальной 


\section{Право и политика $2(170) \cdot 2014$}

справедливости в интерпретации ислама прозвучала в Конституции Индонезии 1945 г., а наиболее полно в Конституции Ирана 1978 г. ${ }^{2}$ Ряд исследователей считает, что Р. фон Моль в своей книге «Наука полиции по началам юридического государства» (русский перевод 1871 года), вышедшей в 1832 году в Германии, также использует понятие социального государства. Под полицией Моль понимал связанную правом деятельность государства по содействию гражданам в достижении ими разумных и дозволенных целей, охраняя при этом их свободу путем принятия общих мер и создания учреждений, которыми может воспользоваться всякий․ Однако наибольшее распространение получило мнение, что дефиниция «социальное государство» была введена в научный оборот немецким государствоведом и экономистом Лоренцем фон Штейном в 1850 г. Сущность социального государства Штейн определил так: «Оно обязано способствовать экономическому и общественному прогрессу всех своих граждан, ибо, в конечном счете, развитие одного выступает условием развития другого и именно в этом смысле следует понимать социальное государство» ${ }^{4}$. Положения о социальных правах граждан и о социальных обязанностях государства в конце XIX - начале XX в. развивали также другие немецкие и австрийские исследователи, американский государствовед и Президент США Вудро Вильсон (он, правда, писал лишь об обязанности государства создать всем равные условия (шансы) и поддерживать определенный уровень жизни), французский конституционалист Леон Дюги, выдвигавший концепцию «государства-добра»5. В российской литературе идеи социальных прав и достойного существования человека в наиболее отчетливой форме выражал государствовед П.И. Новгородцев (1909 г. $)^{6}$. Тут необходимо отметить, что для России характерны

\footnotetext{
${ }^{2}$ См.: Путило Н.В., Цомартова Ф.В., Доронин Ю.А. 15-летию Конституции Российской Федерации посвящается (обзор научнопрактической конференции «Конституция, закон и социальная сфера общества») // Журнал российского права. 2008. № 12.

${ }^{3}$ См.: Моль Р. Наука полиции по началам юридического государства. СПб., 1871.

${ }^{4}$ См.: Штейн Л. фон. История социального движения Франции с 1789 года. СПб.: Тип. А.М. Котомина, 1872; Штейн Л. фон. Учение об управлении и право управления с сравнением литературы и законодательств Франции, Англии и Германии. СПб. Изд. А.С. Гиероглифова, 1874.

${ }^{5}$ См.: Честнов И.Л. Легитимность как критерий социального государства в эпоху постмодернизма // Социальное правовое государство. Вопросы теории и практики: Материалы межвузовской научно-практической конференции, 21 июня 2003 г. СПб., 2003. С. 60.

${ }^{6}$ См.: Новгородиев П.И. Кризис современного правосознания. M., 1909.
}

были рассуждения об особом понимании государства как государства правды, что ярко проявляется в работах ученых -правоведов, сторонников евразийской концепции права: Н.Н. Алексеева, П.И. Савицкого, Г.В. Вернадского, Г. Флоровского, М.В. Шахматова. Идея социального государства, таким образом, находила свое отражение как в западной, так и российской научной мысли. История развития идеи социального государства насчитывает несколько столетий, однако на взгляд автора, и на сегодняшний день, ровно как и несколько столетий назад, единство в понимании и наполнении указанного термина отсутствует. При этом не дает ответа о конкретных параметрах социального государства и Конституция России. Дело в особенности самих социальных проблем - в их постоянной динамике, взаимосвязанной с экономическими и политическими процессами в обществе. По мнению автора, понятие «социальное государство» включает в себя многовекторные направления социальной политики, предметное поле которой складывается из таких социальных элементов как занятость населения, образование, охрана здоровья, социальное обеспечение, обеспечение жильем и др. Термин «социальное государство» не является застывшей фиксированной догмой и, на наш взгляд, его наполнение, представление государства социальным во многом определяется степенью признания и реализации конституционного права граждан на социальное обеспечение в том или ином государстве. Конституционное право граждан на социальное обеспечение является тем индикатором, той «лакмусовой бумажкой», эффективность реализации которого позволяет говорить о социальности государства. Идеи, размышления, те или иные течения в понимании государственного устройства, зачастую антагонизирующие друг другу, являются лишь отдельными элементами, набросками к концепции социального государства, и до 1949 г. в конституциях терминологически не использовалось словосочетание «социальное государство». Таким образом, как мы видим, в сочинениях мыслителей на разных этапах человеческой истории имеются рассуждения об элементах, как бы мы сказали теперь, социальности государства, но начиная и с первых веков текущего тысячелетия и, пожалуй, до начала XX в. ни идеи социального государства, ни заметных социальных мер со стороны государства не было.

Можно по разному определять истоки зарождения учений о социальном государстве, но бесспорным остается факт, что лишь после Второй мировой войны появляется легальное закрепление идеи социального государства в конституциях стран мира. 
При анализе зарубежных конституций можно отметить, что понятие социальности государства, его наполнения через фиксацию права на социальное обеспечение в тексте Основного Закона практически не встречается. Анализируя зарубежные конституции на предмет закрепления принципов, целей, основополагающих начал социальной политики государства, можно выделить несколько групп.

К первой группе стран относятся те, в конституциях которых не содержится упоминание о государственной социальной политике и как следствие отсутствует закрепление, в том числе и социальных прав: Великобритания, Бельгия, Нидерланды, Финляндия, США, Япония.

Вторую группу составляют государства, в конституциях которых закреплены только некоторые социальные права человека, составляющие отдельные элементы права на социальное обеспечение. К примеру, Конституция Венгерской Республики 1994 г. гарантирует право социальной безопасности, право на материальное обеспечение в старости, в случае болезни, инвалидности, потери супруга, сиротства и в связи с безработицей, возникшей не по их вине (ст. 70/Е. (1)). ${ }^{7}$ В соответствии со ст. 45.1 Конституции Ирландии 1937 г. государство обязано содействовать благосостоянию всего народа, защищая и обеспечивая социальный порядок ${ }^{8}$. Конституция Королевства Бахрейн 2002 г. закрепляет право каждого на получение медицинской помощи, заботу о здоровье и гарантию средств для предупреждения заболеваний и лечения, учреждая больницы (ст. 8)9.

К следующей группе принадлежат конституции, в тексте которых закреплены и подробно детализированы социальные права граждан.

В главе 3 Конституции Испании 1978 г. к основополагающим принципам социально-экономической политики относятся: обеспечение правовой, экономической и социальной защиты семьи, всесторонней

\footnotetext{
${ }^{7}$ См.: Конституция Венгерской Республики. Конституции государств Европы. В 3 т. Т. 1 / Под общей ред. Л.А. Окунькова. М.: HOPMA, 2001. C. 562.

${ }^{8}$ См.: Конституция Ирландии. Конституции государств Европы. В 3 т. Т. 1 / Под общей ред. Л.А. Окунькова. М.: НОРМА, 2001. C. 814.

${ }^{9}$ См.: Конституция Королевства Бахрейн. Конституции государств Азии. В 3 т. / Под ред. Т.Я. Хабриевой. М.: Институт законодательства и сравнительного правоведения при Правительстве Российской Федерации; Норма, 2010. Т. 1: Западная Азия. С. 32.
}

защиты детей (ч. 1, 2 ст. 39); создание благоприятных условий для социального и экономического развития, для более справедливого распределения региональных и личных доходов в рамках политики экономической стабильности (ст. 40); поддержка государственной системы социального страхования, обеспечивающей всем гражданам необходимую помощь и социальные услуги, прежде всего при безработице $(\text { ст. } 41)^{10}$. В главе третьей подробно закреплены социальные права испанцев (ст. $42-52)$, а в главе $4-$ гарантии основных прав и свобод.

К принципам государственной политики Бутана относится «стремление государства осуществлять принципы государственной политики в целях обеспечения достойного существования народа Бутана в развивающейся и богатой стране» (ч. 1 ст. 9). В частях $12-15,21-22$ ст. 9 детально урегулированы права на труд, образование, здравоохранение, социальное обеспечение ${ }^{11}$. В Конституции Республики Индии 1949 г. в части IV сформулированы руководящие принципы социальной политики. «Государство проводит политику, направленную на обеспечение того, чтобы: а) граждане в равной степени имели права на достаточные средства к существованию; d) существовало равное вознаграждение за равный труд для мужчин и женщин; е) здоровье и силы рабочих, а также малолетних детей не подвергались злоупотреблениям; f) дети имели возможность развиваться в необходимых для их здоровья условиях, обеспечивающих свободу и достоинство, а детство и юность пользовались защитой от эксплуатации и моральной и материальной зависимости» (ст. 39) ${ }^{12}$.

Политическая Конституция Колумбии 1991 г. основной социальной целью деятельности государства ставит «удовлетворение потребностей населения в области здравоохранения, образования, обеспечения проживания в благоприятной окружающей среде и питьевой водой. Для достижения этой цели расходы на социально-культурные мероприятия преобладают в планах экономического

\footnotetext{
${ }^{10}$ См.: Конституция Испании 1978 г. Конституции государств Европы. В 3 т. Т. 2 / Под ред. и со вступительной статьей директора Института законодательства и сравнительного правоведения при Правительстве Российской Федерации Л.А. Окунькова. М.: НОРMA, 2001. C. $58-61$.

${ }^{11}$ См.: Конституция Королевства Бутан 2008 г. Конституции государств Азии. В 3 т. / Под ред. Т.Я. Хабриевой. Т. 2: Средняя Азия и Индостан. С. 141.

${ }^{12}$ Конституция Королевства Бутан 2008 г. Конституции государств Азии. В 3 т. / Под ред. Т.Я. Хабриевой. Т. 2: Средняя Азия и Индостан. С. 256.
} 


\section{Право и политика $2(170) \cdot 2014$}

развития и государственном бюджете над любыми другими» (ст. 366) ${ }^{13}$.

К основополагающим началам социальной и экономической политики Основного Закона Султаната Оман относятся: защита семьи; охрана материнства и детства; несовершеннолетних и лиц, не способных заботиться о себе самостоятельно по причине болезни, недееспособности, преклонного возраста, вынужденной безработицы; обеспечение возможностей трудоустройства для всех граждан и подготовки их к труду (ст. $15-20)^{14}$. В Конституции Республики Филиппины в «Декларации принципов и государственной политики» (раздел 9) «государство осуществляет справедливую и динамичную социальную политику, которая обеспечивает процветание и независимость государства, освобождение народа от бедности при обеспечении соответствующих социальных услуг, полной занятости, растущего уровня жизни и улучшения качества жизни каждого» ${ }^{15}$.

Таким образом, во многих зарубежных странах элементы системы государственной социальной политики детально урегулированы на уровне конституций. Нормы вышеуказанных Конституций зарубежных государств возможно применять и Российской Федерации для совершенствования отечественной Конституции и для развития, становления социального государства, поскольку, по мнению С.А. Авакьяна, «мы еще далеки от «настоящего» социального государства, ст.7 Конституции можно рассматривать как стратегическую задачу общества и государства не только на ближайшие годы, но и десятилетия» ${ }^{16}$. В.Г. Баев и А.Е. Шуняева резюмируют, что формирование социального государства в России находится на самом раннем этапе: разработка концепции только начинается. Государственное управление в большинстве случаев осуществляется без реальной опоры на юридическую доктрину, нормативная база - неполная, определены лишь некоторые конституционные обязанности Российского государства в области социальной политики по отношению к его

\footnotetext{
${ }^{13}$ См.: Политическая Конституция Колумбии 1991 г. Конституции государств Америки. В 3 т. / Под ред. д.ю.н., проф. Т.Я. Хабриевой. М.: Институт законодательства и сравнительного правоведения при Правительстве Российской Федерации, 2006. T. 3. Южная Америка. С. 757.

${ }^{14}$ См.: Белая книга. Основной Закон Султаната Оман. Конституции государств Азии. В 3 т. / Под ред. Т.Я. Хабриевой. Т. 1: Западная Азия. С. 461.

${ }^{15}$ См.: Конституция Республики Филиппины 1987 г. Конституции государств Азии. В 3 т. / Под ред. Т.Я. Хабриевой. Т. 3: Дальний Восток. С. 925.

${ }^{16}$ См.: Авакьян С.А. Конституционное право России: Учебный курс. 2-е изд., перераб. и доп. В 2 т. Т. 1. М.: Юристъ, 2007. С. 359.
}

гражданам ${ }^{17}$. В этой связи интересным для разработки национальной концепции социального государства представляется наследие сторонников евразийской концепции права, согласно которой, для России характерно особое понимание государства как «государства правды - правления Божественных начал добра, любви, справедливости, правды в земной жизни людей» ${ }^{18}$.

Рассматривая западную модель социального государства, индикатором социальности причем определяя конституционное право на социальное обеспечение, и как, концентрированное выражение этого права, право на социальную помощь, остановимся на США как классическом образце западной модели государственного устройства с рыночной экономикой. Поскольку экономика страны основана на системе частновладельческого капитализма и свободном предпринимательстве, нередко складывается представление, будто американские граждане должны всегда заботиться о себе сами. Верно, что американцы должны сами удовлетворять свои потребности, и для большинства умение обойтись без помощи сограждан и государства - дело чести. Но верно и то, что с 1930-х годов Соединенные Штаты создавали разветвленную систему социального обеспечения для тех, кто оказался не в состоянии позаботиться о себе сам. В конце 19-начале 20 века ряд стран - в том числе Германия, Франция, Британия и Швеция - начали вводить финансируемые и управляемые правительством программы социального обеспечения граждан. В США ничего подобного не происходило. Как заметил о Соединенных Штатах того периода один автор, «Бедным в их нужде здесь не помогает никто» ${ }^{19}$. До 1930-х годов подобный подход превалировал в Америке, и федеральное правительство никакой помощи бедным и нуждающимся не оказывало. Система социального обеспечения в США, права на социальное обеспечение и как элемент этого права, право на государственную социальную помощь начала складываться с первых дней президенства Франклина Делано Рузвельта и на протяжении всего XX века претерпевала серьезные трансформации, связанные, в том числе и с идеологическими установками политических сил, находившимися в тот или иной период времени у власти в стране. Основой развития государственного социального обеспечения в США стал Закон о социальном обеспечении 1935 г.

\footnotetext{
${ }^{17}$ См.: Баев В.Г., Шуняева А.Е. Социальное государство: понятие, содержание, конституционное закрепление // Конституционное и муниципальное право. 2008. N 17. С. 12 - 17.

${ }^{18}$ См.: Шахматов М.В. Государство правды. М., 2008. С. 5.

${ }^{19}$ См.: Ричард Поуэлек. Система социального обеспечения в Америке// http:/ /www. 4uth.gov. ua /usa/ russian/ society/socialsec.htm.
} 
Он предусматривал создание двух программ общенационального масштаба по социальному обеспечению пожилых и безработных. Первая программа заложила основу федеральной системы предоставления льгот престарелым и пенсионерам, проработавшим в промышленном и торговом секторах. Вторая программа предусматривала создание системы социального страхования для безработных. Программы медицинской помощи нуждающимся детям, престарелым инвалидам; помощь из средств федерального бюджета детям, живущим в малообеспеченных семьях или с одним из родителей или родственников; денежную помощь из средств федерального бюджета слепым, полным и пожизненным инвалидам; финансовую помощь штатам на охрану материнства и детства. Законом также предусматривалось предоставление федеральных грантов штатам для обеспечения реализации программ по поддержке престарелых и инвалидов (в основном, слепых). Система социального обеспечения в США столь широка, что в начале и середине 1980-х годов почти половину всех расходов федеральной казны составляли выплаты на «социальные нужды», то есть на оказание помощи людям. Это в два раза больше, чем в 60-х годах, когда на обеспечение социальных программ расходовалось лишь около 25 процентов федерального бюджета. Программы помощи бедным включают:

Пособия по социальному обеспечению - ежемесячные суммы, выплачиваемые государством тем, чей доход не обеспечивает таких основных потребностей, как пища, кров и одежда.

Медикейд - оказание бесплатной медицинской помощи и госпитализации.

Продовольственные купоны - книжечки специальных талонов, действительных для приобретения продуктов в любом магазине.

Школьное питание - бесплатные завтраки и обеды для школьников.

Распределение избытков продовольствия - в рамках этой программы правительство скупает огромное количество продовольственных продуктов и бесплатно распределяет их среди бедных семей ${ }^{20}$.

В настоящее время будущее существования программ и всей системы социального обеспечения в Соединенных Штатах не стоит под вопросом. Но масштаб системы и направление ее развития будут зависеть от консенсуса, к которому придет американский народ, взвесив все достоинства и недостатки. Одни считают,

${ }^{20}$ См.: Ричард Поуэлек. Система социального обеспечения в Америке// http://www. 4uth.gov. ua/usa/ russian/ society/socialsec.htm. что федеральному правительству следует использовать свою власть и средства и сделать все возможное для искоренения бедности и обеспечения каждого, кто не способен обеспечить себя сам. В этом они видят одну из основных обязанностей правительства.

Другие требуют введения строгих ограничений на финансируемые правительством программы социального обеспечения. Эти программы, утверждают их оппоненты, слишком дороги, неэффективны и лишают неимущих стимула трудом добиваться образования, профессиональной квалификации и рабочих мест, которые позволили бы им вырваться из нищеты. Взамен они предлагают сохранить на минимально допустимом уровне страховые принципы программы для нетрудоспособных и действительно нуждающихся, а лучший способ помощи бедным видят в дальнейшем развитии экономики в целом. Программы социального обеспечения, говорят они, требуют денег, и эти средства приходится изымать у работающих членов среднего класса, которые сами нуждаются в этих деньгах, чтобы содержать семьи и обеспечивать крепкую экономику. И, наконец, указывают они, каждая новая программа социального обеспечения требует нового штата чиновников для ее проведения, что удорожает содержание правительственного аппарата.

Где же лежит истина? Многие наблюдатели утверждают, что в Соединенных Штатах уже начинает складываться постоянный «подкласс» людей, из поколения в поколение живущих за счет социального обеспечения. С другой стороны, одно из проведенных исследований показало, что в 1970-х годах в Соединенных Штатах такого постоянного класса не существовало. В среднем каждый неимущий пользовался социальным обеспечением от двух до трех лет; в конечном же счете почти все, жившие на пособие, устраивались на работу и добивались более обеспеченного образа жизни. Однако другое исследование, проведенное в 1985 году, зарегистрировало увеличение числа бедных.

Все исследования и дебаты вокруг бедности и программ социального обеспечения ясно демонстрируют обеспокоенность американцев нерешенной проблемой. Расходятся они лишь в вопросе о необходимой степени участия правительства в ее решении. Одни верят, что сокращение пособий заставит бедных активнее стремиться стать на ноги и упорнее искать работу. Они считают, что снижение налогов и, следовательно, расходов на содержание правительства, повысит покупательную способность населения и стимулирует рост деловой активности. Оживление деловой активности обеспечит работой всех — или почти всех. Другие считают такой 
DOI: $10.7256 / 1811-9018.2014 .2 .10897$

При цитировании этой статьи сноска на dоі обязательна

\section{Право и политика $2(170) \cdot 2014$}

подход нереалистичным. С их точки зрения, правительство, будучи гарантом общественного благосостояния, обязано сделать все возможное для ликвидации бедности. Только время и искренние всенародные усилия обеспечить наивысший возможный уровень жизни каждому жителю страны определят, какой подход окажется более эффективным. ${ }^{21}$

С 30-х годов прошлого столетия, пожалуй, можно говорить о том, что к США вполне применим термин «социальное государство». Это фактически ознаменовало признание изменившейся природы государственности. Данное понятие отразило свершившийся переход от «полицейского» государства, «государства общественного договора», «государства как высшей формы власти» к государству, осуществляющему социальные функции. А значит, оно берет на себя ответственность за благосостояние граждан, обеспечивает доступность социальной поддержки всем членам общества, создает государственные системы социального обеспечения и социальной защиты, вводит бюджетное финансирование социальных программ и новые механизмы социальной политики в виде государственного социального страхования, становится доминирующим субъектом социальных функций в обществе.

Первая треть XX в. в США (да и во многих странах Европы) ознаменовалась лавинообразным принятием социальных законов и инкорпорирование в политику многих стран принципов социального государства. В эти годы были приняты законы, связанные с социальным и медицинским страхованием, пенсионным обеспечением, пособиями по безработице, семейными пособиями и страхованием от несчастных случаев. Социальное законодательство стало не просто сектором правового поля, но начало оказывать мощное влияние на правовое содержание всей нормативной базы государств, стало тем индикатором который отражал степень и наличие социальности государства. В 1930г. Г.Геллер ввел понятие «социальное правовое государство», которое акцентирует право гражданина на социальных гарантиях со стороны государства. Констатация правовой природы социального государства фактически закрепила за государством его социальные функции. Социальные функции последнего не просто приобрели правовые основания, но стали ведущими для государства, трансформируя, в свою очередь, правовую базу государства. Личные права человека стали краеугольным камнем всей правовой

${ }^{21}$ См.: Ричард Поуэлек. Система социального обеспечения в Америке// http://www. 4uth.gov. ua /usa/ russian/ society/socialsec.htm. системы государства, определяя через избирательное право власть, через гражданские права - политическую природу государства и его социальные обязанности, через социальные права - его социальные функции. Правовой фундамент придал социальным функциям обязательный характер. Социальные функции стали неотъемлемой частью функциональной структуры государства.

Следующему этапу развития представлений о социальном государстве начало положил знаменитый доклад В.Бевериджа «Полная занятость в свободном обществе», с которым он выступил в английском парламенте в 1942 г. В нем были изложены основные принципы «государства всеобщего благосостояния», впервые выдвинута идея гарантированного единого национального минимального дохода, подчеркнута тесная связь социальной политики с государственной экономической политикой, нацеленной на обеспечение полной занятости. С этого времени термин «государство благосостояния» - «welfare state» - стал в англоязычных странах синонимом социального государства. ${ }^{22}$

Таким образом, конец XIX века и XX век характеризуется становлением и развитием социальных прав человека и гражданина, права на социальное обеспечение, развитие и закрепление которого в национальных системах законодательства является индикатором социальности государства.

Начало XXI века и для Запада и для России характеризуется тем, что, и Россия, где по сути становление социального государства, эффективная реализация права граждан на социальное обеспечение это скорее протокол о намерениях, и западные страны, состоявшиеся как зрелые социальные государства, в настоящее время испытывают серьезный кризис. Это связано с двумя факторами. Первое - масштабный экономический кризис поставил перед многими социальными системами ряд вызовов, но, с другой стороны, это не временное явление. Просто переход общества в постиндустриальную эпоху требует других механизмов, других подходов других инструментов.

И в этой связи представляется безальтернативным паритетное участие государства и общества и, как следствие каждого гражданина, в строительстве и существовании социального государства с институтами взаимообусловленной ответственности. Такого рода взаимную ответственность можно ярко проиллюстрировать на примере института государственной социальной помо-

\footnotetext{
${ }^{22}$ Beveridge W. Full Employment in Free Society. - London, Allen \& Unwin, 1944.
} 
щи нуждающимся гражданам. Условием, влияющим на предоставление государственной социальной помощи в натуральном или в денежном выражении, должно являться условие приложения собственных усилий для преодоления кризисной ситуации. Наличие такого условия в законодательстве европейских государств обусловлено целями предоставления помощи нуждающимся. Европейские власти подходят к предоставлению помощи практично и предоставляют деньги лишь тем, кто действительно в них нуждается. Это позволяет снизить количество получателей с одновременным увеличением размеров выплат и более индивидуальным подходом. Закрепление обязанности гражданина с помощью государства преодолеть состояние нищеты не только путем получения денег от властей, но и путем применения различных механизмов его скорейшего возвращения к нормальной жизни, устройства на более оплачиваемую работу ${ }^{23}$. Социальная помощь в ФРГ призвана помочь попавшим в нужду людям снова встать на ноги, при этом имеется в виду не только и не столько материальная поддержка, сколько помощь в поиске работы. На практике, однако, это означает, что если получатель в течение определенного времени был не в состоянии найти работу, то он обязан принять работу, предложенную социальным ведомством. Отказ может быть рассмотрен как злостное уклонение, а это может, в свою очередь, привести к сокращению или даже лишению социальной помощи (§ 25 Abs. 1 BSHG). Отказаться от социальной работы без риска потерять пособие можно только в исключительных случаях (§ 18 Abs. 3 S. 1 - 4 BSHG). Социальное ведомство обязано контролировать, а зачастую и оказывать определенное давление на работоспособного получателя помощи с целью заставить его искать работу (§ 18 Abs. 2 S. 1 BSHG). Сам получатель помощи также обязан регулярно предоставлять социальному ведомству результаты своих усилий по поиску работы (отказы на резюме, вырезки из газет с объявлениями о поиске работы и пр.).

Согласно законодательству Франции претендент на пособие обязан согласиться на интеграцию направленной деятельности. В отличие от ФРГ интеграция получателя пособия во Франции не обязательно должна быть направлена на оплачиваемую работу, обучение и ученичество считаются также имеющими силу целями ${ }^{24}$.

\footnotetext{
${ }^{23}$ См.: Кожевников Д.Е. Кто имеет право на социальную помощь? Критерии, определяющие право на государственную социальную помощь в России и странах Европы // Социальное и пенсионное право. 2010. № 3. С. 9 - 17.

${ }^{24}$ См.: Данни Питерс. Введение в законодательство о социальной защите в странах - членах Европейского сообщества // Серия
}

В России, в отличие от Германии и аналогичных правил в других странах, в Федеральном законе «О государственной социальной помощи» не закреплена обязанность малоимущего гражданина приложить максимум собственных усилий для преодоления состояния бедности. Такая обязанность, по нашему мнению, была бы крайне полезна и для нашего государства для стимулирования малоимущих к поиску более высокооплачиваемой работы, выходу из кризисного состояния и интеграции в общество. Однако такая обязанность должна коррелировать с обязанностью государства предоставить гражданину помощь нематериального характера. Более того, круг получателей социальной помощи в европейских странах сводится к лицам, не имеющим или потерявшим работу. Намного проще и качественнее решить данную проблему можно, всего лишь установив минимальную заработную плату и пенсии на уровне хотя бы прожиточного минимума, а если действительно следовать социальной направленности государства и принять опыт европейских стран, то на уровне минимального потребительского бюджета. Таким образом, мы видим, что состояние социального благополучия, достойного уровня жизни является зоной ответственности и влияния как государства, так и каждого отдельно взятого гражданина.

В соответствии со статьей 39 Конституции Российской Федерации каждому гарантируется социальное обеспечение по возрасту, в случае болезни, инвалидности, потери кормильца, для воспитания детей и в иных случаях, установленных законом. Государственные пенсии и социальные пособия устанавливаются законом. Поощряются добровольное социальное страхование, создание дополнительных форм социального обеспечения и благотворительность. Элементом права на социальное обеспечение являются, наряду с прочим, в том числе и отношения по предоставлению различных социальных услуг, удовлетворяющих основные запросы человека. В настоящее время, учитывая современную ситуацию, а также ожидаемый к 2018 году рост потребности населения Российской Федерации в социальных услугах, в том числе и услуг социального обслуживания в связи со старением населения (численность населения старше трудоспособного возраста, по прогнозу Росстата, увеличится за 2010-2017 годы с 30,7 до 35,2 млн. чел., или на 14,6\%) тенденцией в развитии механизма реализации права на социальное обеспечение является повышение качества услуг, оказываемых

публикаций Левенского института Центральной и Восточной Европы. 1994. № 2. С. 60. 


\section{Право и политика $2(170) \cdot 2014$}

в социальной сфере. Об этом прямо заявил Президент Российской Федерации В.В. Путин в своем Послании Федеральному Собранию Российской Федерации, «Важнейшая задача - создание системы независимой оценки качества социальных учреждений....Считаю, что нужны законодательные нормы прямого действия, которые определят единые подходы, стандарты и критерии, а также обязательства всех уровней власти по созданию системы независимой оценки качества работы организаций социальной сферы». ${ }^{25}$

Другим перспективным направлением в развитии права на социальное обеспечение и, как следствие, повышения социальности государства, является «развитие реальной конкуренции, открытие бюджетной сферы для НКО и социально ориентированного бизнеса» ${ }^{26}$. Именно о решении этой задачи шла речь на прошедшем в г. Москве 15-18 января 2014 года Гайдаровском форуме «Россия и мир: устойчивое развитие». На пленарной дискуссии «Стратегическая инициатива государства - расширение доступа бизнеса в социальную сферу» разговор шел о дорожной карте по допуску бизнеса в социальную сферу, которую разработало Агентство стратегических инициатив. Необходимость качественных социальных услуг, их востребованность, снижение государственных затрат, дополнение усилий и средств государства в социальной сфере усилиями и средствами негосударственных структур, коммерческих и некоммерческих без вытеснения государства, повышение конкуренции в области оказания социальных услуг, a, значит, повышение их качества, расширение социальных инноваций, то есть появление услуг нового качества - вот основные направления развития государственной социальной политики, в том числе и в сфере социального обеспечения населения. ${ }^{27}$

Социальное государство, функционирующее как социальный институт макроуровня, формирует свою структуру и организует жизнедеятельность всех сфер общества, опираясь на конституционные основы. Наша страна провозглашена социальным государством согласно ст. 7 Конституции РФ. Сферой государственной ответственности должна остаться государственная со-

${ }^{25}$ См.: Послание Президента РФ Федеральному Собранию от 12.12.2013 // «Российская газета», № 282, 13.12.2013.

${ }^{26}$ См.: Послание Президента РФ Федеральному Собранию от 12.12.2013 // «Российская газета», № 282, 13.12.2013.

${ }^{27}$ См.: В третий день Гайдаровского форума прошла пленарная дискуссия «Стратегическая инициатива государства - расширение доступа бизнеса в социальную сферу»// http://www.gaidarforum. $\mathrm{ru} / \mathrm{ru} / \mathrm{full}$. циальная помощь малообеспеченным семьям, которая постепенно заменит собой действующую социально неоправданную и крайне неэффективную систему льгот и компенсаций. Приоритеты России в реализации социальной политики и укреплении социально-экономических основ социального государства меняются в зависимости от внутренней и международной политической и социально-экономической ситуации. В условиях структурного глобального кризиса мировой экономической системы и связанного с этим снижающегося уровня жизни людей на первый план выдвигается борьба с бедностью, ставятся задачи создания высококвалифицированных рабочих мест, усиления регулятивных функций сферы социального обеспечения в целях сохранения социальной стабильности и социального мира.

\section{Библиография:}

1. Авакьян С.А. Конституционное право России: Учебный курс. 2-е изд., перераб. и доп. В 2 т. Т. 1. М.: Юристь, 2007. С. 359.

2. Баев В.Г., Шуняева А.Е. Социальное государство: понятие, содержание, конституционное закрепление // Конституционное и муниципальное право. 2008. № 17. C. 12-17.

3. Beveridge W. Full Employment in Free Society. London, Allen \& Unwin, 1944.

4. Данни Питерс. Введение в законодательство о социальной защите в странах-членах Европейского сообщества // Серия публикаций Левенского института Центральной и Восточной Европы. 1994. № 2. C. 60 .

5. Кожевников Д.Е. Кто имеет право на социальную помощь? Критерии, определяющие право на государственную социальную помощь в России и странах Европы // Социальное и пенсионное право. 2010. № 3. C. 9-17.

6. Моль Р. Наука полиции по началам юридического государства. СПб., 1871.

7. Новгородцев П.И. Кризис современного правосознания. М., 1909.

8. Хабриева Т.Я. Конституции государств Америки. В 3 т. / Под ред. д.ю.н., проф. Т.Я. Хабриевой. М.: Институт законодательства и сравнительного правоведения при Правительстве Российской Федерации, 2006. Т. 3. Южная Америка. С. 757.

9. Путило Н.В., Цомартова Ф.В., Доронин Ю.А. 15-летию Конституции Российской Федерации посвя- 
DOI: 10.7256/1811-9018.2014.2.10897

При цитировании этой статьи сноска на doi обязательна

Человек и государство

щается (обзор научно-практической конференции «Конституция, закон и социальная сфера общества») // Журнал российского права. 2008. № 12.

10. Ричард Поуэлек. Система социального обеспечения в Америке// http:/ /www. 4uth.gov. ua /usa/ russian/ society/socialsec.htm.

11. Честнов И.Л. Легитимность как критерий социального государства в эпоху постмодернизма // Социальное правовое государство. Вопросы теории и практики: Материалы межвузовской научно-практической конференции, 21 июня 2003 г. СПб., 2003. С. 60.

12. Шахматов М.В. Государство правды. М., 2008. С. 5.

13. Штейн Л. фон. История социального движения Франции с 1789 года. СПб.: Тип. А.М. Котомина, 1872.

14. Штейн Л. фон. Учение об управлении и право управления с сравнением литературы и законодательств Франции, Англии и Германии. СПб.: Изд. А.С. Гиероглифова, 1874.

15. Агеев В.Н. Правомерность ограничения прав и свобод государственных служащих в Российской Федерации: правовая оценка Конституционного Суда // NB: Вопросы права и политики. - 2013. 1. - C. 166 - 189. URL: http://www.e-notabene.ru/lr/ article_394.html

16. Глигич-Золотарева М.В. «Увлечение общими местами» и ценностный компонент конституционализма // NB: Проблемы общества и политики. 2013. - 3. - C. 296 - 317. URL: http://www.e-notabene. $\mathrm{ru} / \mathrm{pr} /$ article_503.html

17. Кодан С.В., Владимирова Г.Е. Юридическая природа Основных государственных законов Российской империи 1832-1892 гг. издания в оценке российских правоведов // NB: Проблемы общества и политики. - 2013. - 6. - С. 218 - 253. URL: http://www.enotabene.ru/pr/article_765.html

18. Гуляихин В.Н. Правовой менталитет российских граждан // NB: Вопросы права и политики. - 2012. 4. -C. 108 - 133. DOI: 10.7256/2305-9699.2012.4.310. URL: http://www.e-notabene.ru/lr/article_310.html

19. Щербанюк О.В. Суверенитет народа как гарантия прав и свобод человека и гражданина // NB: Вопросы права и политики. - 2013. - 10. - C. 131 - 148. URL: http://www.e-notabene.ru/lr/article_9610.html

20. Смирнова Е.С. Проблемы пребывания иностранных граждан на территории государства и вопросы обеспечения их безопасности // NB: Международное право. - 2013. - 2. - С. 39 - 66. URL: http://www.e-notabene.ru/wl/article_676.html

\section{References (transliteration):}

1. Avak'yan S.A. Konstitutsionnoe pravo Rossii: Uchebnyi kurs. 2-e izd., pererab. i dop. V 2 t. T. 1. M.: Yurist', 2007. S. 359.

2. Baev V.G., Shunyaeva A.E. Sotsial'noe gosudarstvo: ponyatie, soderzhanie, konstitutsionnoe zakreplenie // Konstitutsionnoe i munitsipal'noe pravo. 2008. № 17. S. 12-17.

3. Beveridge W. Full Employment in Free Society. London, Allen \& Unwin, 1944.

4. Danni Piters. Vvedenie v zakonodatel'stvo o sotsial'noi zashchite v stranakh-chlenakh Evropeiskogo soobshchestva // Seriya publikatsii Levenskogo instituta Tsentral'noi i Vostochnoi Evropy. 1994. № 2. S. 60.

5. Kozhevnikov D.E. Kto imeet pravo na sotsial'nuyu pomoshch'? Kriterii, opredelyayushchie pravo na gosudarstvennuyu sotsial'nuyu pomoshch' v Rossii i stranakh Evropy // Sotsial'noe i pensionnoe pravo. 2010. № 3. S. 9-17.

6. Mol' R. Nauka politsii po nachalam yuridicheskogo gosudarstva. SPb., 1871.

7. Novgorodtsev P.I. Krizis sovremennogo pravosoznaniya. M., 1909.

8. Khabrieva T.Ya. Konstitutsii gosudarstv Ameriki. V 3 t. / Pod red. d.yu.n., prof. T.Ya. Khabrievoi. M.: Institut zakonodatel'stva i sravnitel'nogo pravovedeniya pri Pravitel'stve Rossiiskoi Federatsii, 2006. T. 3. Yuzhnaya Amerika. S. 757.

9. Putilo N.V., Tsomartova F.V., Doronin Yu.A. 15-letiyu Konstitutsii Rossiiskoi Federatsii posvyashchaetsya (obzor nauchno-prakticheskoi konferentsii "Konstitutsiya, zakon i sotsial'naya sfera obshchestva") // Zhurnal rossiiskogo prava. 2008. № 12.

10. Richard Pouelek. Sistema sotsial'nogo obespecheniya v Amerike// http:/ /www. 4uth.gov. ua /usa/ russian/ society/socialsec.htm.

11. Chestnov I.L. Legitimnost' kak kriterii sotsial'nogo gosudarstva v epokhu postmodernizma // Sotsial'noe pravovoe gosudarstvo. Voprosy teorii i praktiki: Materialy mezhvuzovskoi nauchno-prakticheskoi konferentsii, 21 iyunya 2003 g. SPb., 2003. S. 60.

12. Shakhmatov M.V. Gosudarstvo pravdy. M., 2008. S. 5.

13. Shtein L. fon. Istoriya sotsial'nogo dvizheniya Frantsii s 1789 goda. SPb.: Tip. A.M. Kotomina, 1872.

14. Shtein L. fon. Uchenie ob upravlenii i pravo upravleniya s sravneniem literatury i zakonodatel'stv Frantsii, Anglii i Germanii. SPb.: Izd. A.S. Gieroglifova, 1874.

15. Ageev V.N. Pravomernost' ogranicheniya prav i svobod gosudarstvennykh sluzhashchikh v Rossiiskoi 
DOI: $10.7256 / 1811-9018.2014 .2 .10897$

При цитировании этой статьи сноска на dоі обязательна

\section{Право и политика $2(170) \cdot 2014$}

Federatsii: pravovaya otsenka Konstitutsionnogo Suda // NB: Voprosy prava i politiki. - 2013. - 1. - C. $166-$ 189. URL: http://www.e-notabene.ru/lr/article_394.html

16. Gligich-Zolotareva M.V. «Uvlechenie obshchimi mestami» i tsennostnyi komponent konstitutsionalizma // NB: Problemy obshchestva i politiki. - 2013. - 3 . - C. 296 - 317. URL: http://www.e-notabene.ru/pr/ article_503.html

17. Kodan S.V., Vladimirova G.E. Yuridicheskaya priroda Osnovnykh gosudarstvennykh zakonov Rossiiskoi imperii 1832-1892 gg. izdaniya v otsenke rossiiskikh pravovedov // NB: Problemy obshchestva i politiki. - 2013. -6. - C. 218 -253. URL: http://www.e-notabene.ru/pr/article_765.html
18. Gulyaikhin V.N. Pravovoi mentalitet rossiiskikh grazhdan // NB: Voprosy prava i politiki. -2012. - 4.C. 108 - 133. DOI: 10.7256/2305-9699.2012.4.310. URL: http://www.e-notabene.ru/lr/article_310.html

19. Shcherbanyuk O.V. Suverenitet naroda kak garantiya prav i svobod cheloveka i grazhdanina // NB: Voprosy prava i politiki. - 2013. - 10. - C. 131 - 148. URL: http:// www.e-notabene.ru/lr/article_9610.html

20. Smirnova E.S. Problemy prebyvaniya inostrannykh grazhdan na territorii gosudarstva i voprosy obespecheniya ikh bezopasnosti // NB: Mezhdunarodnoe pravo. -2013. - 2. - C. 39-66. URL: http://www.e-notabene. ru/wl/article_676.html 